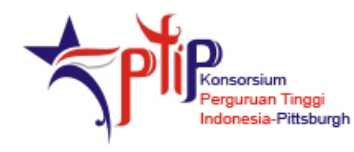

\title{
Active Learning and Student Engagement in Mathematics at Madrasah Ibtidâ'iyah Al-Jauharotunnaqiyah
}

\author{
Ir. Kartina, ${ }^{\text {a }}$ Udi Samanhudi, ${ }^{\text {a, }}{ }^{,}$Siti Aisyah, ${ }^{\text {a }}$ Lukman Nulhakim, ${ }^{a}$ \\ Sutrisno Sadji Evendi, ${ }^{a}$ and Maman Faturohman ${ }^{a}$ \\ ${ }^{a}$ University of Sultan Ageng Tirtayasa, Indonesia
}

\begin{abstract}
Teaching for active learning has been widely recognized as a more effective teaching methodology than traditional transmission models of teaching. However, numerous studies have documented the persistence of traditional teaching methods despite the extensive research literature on the effectiveness of teaching for active learning and frequent efforts to train teachers to use this approach in their classrooms. In this article a team of lecturers from the University of Sultan Ageng Tirtayasa (UNTIRTA: Universitas Sultan Ageng Tirtayasa) in Indonesia report on an action research project carried out at an elementary-level madrasah in the city of Cilegon. Members of the team gathered qualitative data through interviews, focus groups, and classroom observations in order to better understand the challenges teachers faced in teaching for active learning before designing and carrying out a collaborative intervention designed to help teachers use active learning strategies in a mathematics classroom.
\end{abstract}

\begin{abstract}
Abstrak
Metode pembelajaran aktif atau active learning kerap diakui lebih efektif dibandingkan model pengajaran transmisi tradisional. Namun, tidak sedikit pula studi yang mendokumentasikan keunggulan metode pengajaran tradisional, disamping banyaknya literatur tentang efektifitas active learning dan ramainya pelatihan aplikasi active learning di kelas. Dalam artikel ini, tim dosen Universitas Sultan Ageng Tirtayasa di Indonesia melaporkan penelitian tindakan kelas di Madrasah Ibtidaiyah di kota Cilegon. Tim dosen mengumpulkan data kualitatif melalui wawancara, diskusi kelompok, dan observasi kelas guna memahami kendala para guru dalam penerapan active learning. Tim ini kemudian merancang dan melakukan intervensi kolaboratif untuk membantu guru menerapkan strategi active learning di kelas Matematika.
\end{abstract}

Key Words: Active Learning, Madrasah, Mathematics, Indonesia

\section{Introduction}

Teaching for active learning is a pedagogical practice with a long history and an extensive body of empirical research testifying to its effectiveness across a wide range of subject matter. In a recent review of the research literature on active learning, for instance, Michael Prince (2004), citing literature reviews by David W. Johnson, Roger T. Johnson, and Karl A. Smith (1998) covering more than 150 studies over the past 90 years, found broad support for all forms of active learning. This support extends internation-

*Corresponding author. Address: Faculty of Education, Sultan Ageng Tirtayasa University, Indonesia.

Email: hudi_samanhudi@yahoo.com. ally as well, with a wide variety of countries encouraging active learning strategies in classrooms at all levels (Stern and Huber 1997). Clearly, teaching for active learning is widely recognized as a more effective method of instruction than traditional transmission models of instruction.

According to Marcia Keyser (2000), key characteristics of active learning - student involvement in more than listening, emphasis on developing skills rather than mere transmission, student engagement in activities, and student exploration of their own attitudes and values - are linked to critical learning domains, such as cognitive learning, affective learning and behavioral learning. In teaching for active learning teachers involve students in the learning process by giving them opportunities to feel and experience the material discussed in the classroom and thus develop the ability to apply what they have learned to their own 
experience. This is in line with Arthur Chickering and Zelda Gamson's $(1987,21)$ assertion that

Learning is not a spectator sport. Students do not learn much just by sitting in class, listening to teachers, memorizing prepackaged assignments, and spitting out answers. They must talk about what they are learning, write about it, relate it to past experiences, apply it to their daily lives. They must make what they learn part of themselves.

Chickering and Gamson further suggest that students must do more than just listen: they must read, write, discuss and be engaged in solving problems. Most importantly, to be actively involved, students must engage in higher-order thinking tasks such as analysis, synthesis and evaluation. They identify seven principles of good practice that help to accomplish this goal: (1) encourage contacts between students and teachers, (2) develop reciprocity and cooperation among students, (3) use active learning techniques, (4) give prompt feedback, (5) emphasize time on task, (6) communicate high expectations, and (7) respect diverse talents and ways of learning. When students know and understand what they are doing, students will learn best in the classroom. Thus teaching for active learning is broadly defined as instructional activities involving students in doing things and thinking about what they are doing.

\section{Active Learning in Indonesia and Banten Province}

Active learning has been a concern of the Indonesian educational system for decades. With regard to the implementation of active learning, the Indonesian government's support for active learning strategies is reflected in national educational policy. Since 1980 to the more recent Teacher Law No. 14, 2005, the government has encouraged teaching for active learning. In response, the Ministry of National Education (responsible for government schools) and the Ministry of Religious Affairs (responsible for Islamic schools) have encouraged schools under their authority to adopt student-centered and active teaching and learning strategies nation-wide. The result has been initiatives such as Active, Creative, Effective and Joyful Learning (PAKEM: Pembelajaran Aktif, Kreatif, Efektif dan Menyenangkan), which has been introduced to teachers at the elementary school level through several training programs, and the USAID-funded Decentralized Basic Education 2 (DBE2), which has provided active learning training to elementary teachers in six provinces as part of a broader effort to improve teaching and learning in Indonesian primary schools. Thus both Indonesian and international education experts see active learning as one way to improve educational quality in the country and help move educators away from a traditional teaching model that disadvantages both teachers and students by encouraging students to become passive objects in the classroom rather than subjects of the learning process. Encouraging interaction between teachers and students as well as student engagement in the learning process by means of such activities as exploring, analyzing, communicating, reflecting, and actually using new information and experience will, the research shows, improve learning and student achievement (Prince 2004; House 2009).

As a new province, the political and educational leaders of Banten believe that educational improvement will foster provincial development; therefore, political and educational leaders have worked to implement national policies on active learning in provincial schools through regionally sponsored trainings in both elementary schools (sekolah dasar) supervised by the Department of Education and Islamic elementary schools (madrasah ibtidâ'iyah) administered by the Ministry of Religious Affairs. These trainings, conducted three to five time in a year, have been supplemented and extended by DBE2 training in many schools in the province.

Despite the considerable evidence for the effectiveness of teaching for active learning, a number of international studies have shown the persistence of transmission models of teaching (Organisation for Economic Co-operation and Development [OECD] 2009) and documented common impediments to teachers' adoption of active learning strategies (Niemi 2002). Such challenges to the dissemination of teaching for active learning have been documented in Indonesia as well (Bjork 2003). Anecdotal evidence from the authors' interaction with madrasah teachers in Banten suggest that these teachers are encountering even more difficulties in implementing either the PAKEM or DBE2 models of active learning, perhaps due to poor teacher and student preparation as well or the generally poorer educational infrastructure of the madrasah system. Consequently, this study was intended to understand the nature of madrasah teachers' difficulties with active learning strategies and then to try out interventions that might facilitate their ability to teach for active learning.

\section{Research Site, Subjects and Methods}

In order to investigate the apparent difficulties teachers of primary-level Islamic schools in Banten were having with teaching for active learning, a team of lecturers from the University of Sultan Ageng Tirtayasa (UNTIRTA: Universitas Sultan Ageng Tirtayasa), in the provincial capital of Serang, designed and carried out an action research project (Stringer 2007) at one 
primary-level madrasah in the city of Cilegon. Members of the team conducted three cycles of interviews and focus group discussions with teachers, the principal, students and parents of Madrasah Ibtidâ'iyah Al-Jauharotunnaqiyah over a period of several months. Data from both interviews and focus group discussions were recorded, transcribed and analyzed holistically and categorically in order to identify themes in the data that might explain the difficulties teachers in this school faced in teaching for active learning and thus point the way to interventions that might help them overcome those difficulties. In addition, to enrich the data, classroom observations were also conducted, recorded and analyzed in a similar fashion. These preliminary data were then discussed with participating teachers in order to reach an agreement on the direction of subsequent research as well as the nature of proposed interventions. Recognizing their need to improve the teaching and learning practices of their school, school officials and teachers consented to the study, setting aside a specific classroom in which the study would be conducted.

Madrasah Ibtidâ'iyah Al-Jauharotunnaqiyah was established in 1992 by a local Muslim leader to provide greater access to basic education for poor children of the Cidunak area of central Cilegon. Most of the residents of Cidunak work as brick makers, market vendors, food producers (e.g., emping, a locally popular snack), and waste recyclers. As a result, roughly half of AlJauharotunnaqiyah's students work after school collecting plastic waste for recycling or making emping for sale in the local market. This complicates the work of the school's teachers and principal as many children come to school tired and unprepared to concentrate on learning. The school, which serves Grades 1-6, is comprised of six classrooms, a teacher's room, and a library room. There are a total of 10 teachers, most of whom hold a four-year college degree. Only two, however, are civil service employees, which, in the Indonesian system, provides for secure employment, better pay, and retirement benefits (Bjork 2003). Most are contractual employees whose employment depends upon the limited operational funding provided by the government

Participants in this study included three teachers, one principal and one parent of a student. After being informed of the nature of the study and its aim to help teachers improve mathematics instruction by employing active learning strategies, participants gave their verbal assent to participation in the study. With the consent of the principal and the individual teacher affected, the team selected one classroom in which to conduct observations and implement interventions.

\section{Initial Findings: Clarifying the Problem}

The first round of data collection conducted at AlJauharontunnaqiyah suggested that many teachers still find it difficult to implement active learning in their teaching practices. According to the teachers interviewed for this study, poor and inadequate school facilities are the main factor preventing teaching for active learning. In addition, the interviews suggest that few teachers are familiar with the key concepts of PAKEM or teaching for active learning. Only two teachers have actually received some training in teaching for active learning from DBE2, and that training has not been disseminated to other teachers in the school. Therefore, only a few of the teachers are even familiar with the concept of active learning, and even fewer are ready to try it out. This is due, in addition to the lack of training, to their definition of their own roles and the discomfort and anxiety that change inevitably creates. And all this is exacerbated by the low pay of teachers, which forces many to teach in other schools or take second jobs, severely limiting the time available to them to prepare for their classes. Consequently, most of them prefer teaching in a traditional teacher-centered rather than a learnercentered fashion, thus their teaching is monotonous. This of course hinders dissemination of active learning strategies such as exploring, creating, and reflecting on learning experiences, despite the fact that such strategies have been shown to be good for students' learning (Silberman 1996). This can be seen in the following statement said by the teacher: "I haven't got any training for active learning and have no idea how to implement it in the class. Besides, I also have only a little time to study more about active learning strategies because I have to teach in other schools for more incomes" (Nira, pseudonym).

Moreover, interviews with teachers also suggest that they see the socioeconomic background of the students as a factor inhibiting their ability to use active learning strategies. A large number of the students in Al-Jauharotunnaqiyah work after school as shop assistants, waste recyclers, and emping makers in order to help support their families. This obviously impacts students' ability to study at home as well as their behavior in school. Students tend to be silent and inactive in class. While they enjoy some classes-Bahasa Indonesia and Islamic studies, for instance - they feel fearful of other subjects, such as mathematics. Teachers report that most appear to prefer their work after school over studying. And all of this is exacerbated by the perception of a majority of the students' parents that their children's education is solely the responsibility of the school. Thus parental support is relatively low. 
Teachers also complained that the material resources of AlJauharoutunnaqiyah were inadequate. Teachers lack access to instructional media as well as the materials necessary to construct their own. The number of textbooks is so limited that students to not have sufficient access to them. For instance, students are not able to take books home with them to study or work on schoolrelated projects. Teachers point to this material poverty of the school as yet another impediment to using active learning strategies in their classrooms.

The team's findings from the first round of data collection led them to focus the second cycle of research on the use of active learning strategies in mathematics in order to try to improve students' engagement in math. According to both teachers' and students' reports, teachers seem to find math the most difficult subject to teach, and students seem to find it the most difficult to learn. With their traditional teacher-centered strategies, teachers said they were unable to do their best in teaching math. For their part, students said they did not like math because it was difficult and because the way their teachers teach the material is static and boring. This of course has implications for student learning: the average for Grade 3 in a math assessment conducted by the research team, for instance, was 5.5 out of a maximum score of 10 .

During classroom observations the team found that students did not voluntarily respond to the teacher's questions, nor did they actively participate in any of the activities the teacher planned for the class. They tended to be passive and seemed to display little interest in learning the material. The teacher said she believed the students looked nervous because of their low achievement levels in math, which was lower than in any other subject offered, and because they were aware of the fact that they would eventually have to pass a national examination in the subject. The teacher noted that her students tended to sit looking straight ahead with a minimal facial expressions, gestures, or verbal utterances. Based on this observation, it appears that the teacher really wanted her students to be more actively engaged in the process of learning math. However, the teacher's instructional strategy was rather monotonous, consisting largely of teacher-centered whole class lectures and the occasional use of a white board. The teachers' techniques did not appear to fit with her goals. Therefore, the research team decided to focus its assistance on helping the teacher develop instructional materials the students could use and introducing collaborative learning activities in the classroom.

\section{Improving Active Learning and Student Engagement in Mathematics}

In her first attempt to use active learning strategies the teacher distributed copies of a source book for math available in the school library to be used by each student and attempted to engage students in more activities, such as group discussions, short classroom presentations, and on-the-spot assessments. The teacher opened the class by reviewing the previous lesson and questioning students what they had learned over the past few days. She then shifted to questions about the lesson at hand, four digit numbers. Some students attempted to respond, but most did so incorrectly. She then proceeded to write numbers on the white board and ask individual students to read aloud what she had written. Those students who were not being called upon were encouraged to keep silent.

After this introduction to the topic, the teacher organized the students into groups of three and distributed copies of questions to be addressed by the group. When they were finished she asked a representative of each group to read their answers aloud while the rest of the class responded in unison with a "yes" or a "no" if the answer was correct or incorrect. The teacher clarified the correct answers when students' answers were incorrect. Before closing the class, the teacher posed on-the-spot questions to be answered by students voluntarily. Those who answered correctly were given a small prize and extra points, rewards which seemed to motivate students as some appeared quite enthusiastic. The teacher concluded the lesson with a five-minute review and a fivequestion comprehension test.

In her reflections on this lesson the teacher noted that a large percentage of the students, almost half, seemed to feel uncomfortable while she was posing on-the-spot questions. Only about half responded while the other half remained silent. This was something the teacher considered in planning her next lesson. This time she utilized instructional media - in the form of geometric shapes-which students were asked to describe collaboratively in groups of three. Instead of quizzing students individually, she circulated among the groups encouraging them to elaborate on their descriptions, mediating differences of opinion among groups, and offering compliments in response to interesting or insightful observations. A comprehension test administered after the lesson seemed to show that students had mastered the concepts taught in the lesson, suggesting that teacher's more facilitative approach in the second lesson may have been more effective than the more teacher-centered approach of the first lesson.

In the second cycle of working with active learning strategies the same teacher continued to experiment with a more facilitative approach to teaching. This lesson focused on Roman numerals, which she had introduced in a previous lesson that engaged students in writing and doing exercises with roman numerals. She opened this class by asking students the students to rearrange the desks in the classroom into a semi-circle. Once they had done so, 
she seated herself in the center of the semi-circle. She then engaged students in a brainstorming activity focused on different types of numbers before writing examples of Roman numerals and their Arabic equivalents on the whiteboard. During these activities she asked students from time to time whether this pairing of numbers was helpful to them. Sometime later in the class period, students were organized again into groups of three and instructed to work together on a worksheet distributed to all students. The teacher then circulated among the groups giving individual assistance to students who were having difficulties. The lesson concluded with individual short presentations and questions from the rest of the class.

In reflections on this lesson, the team noted that many students still seemed to be happy with their silences. During the short presentations, for instance, many of them were hesitating to ask questions or offer responses. In subsequent lessons therefore the team attempted to encourage more active student participation by forming larger groups and giving specific responsibilities to each individual student. Each student was asked to finish a different number of questions discuss them after 20-30 minutes. Upon completion of this task representatives of each group were asked to give short presentations before the class. A comprehension test administered after the lesson suggested that slightly more than half of the students met the teacher's goal.

\section{Discussion and Conclusion}

Based on initial observations that most of the students displayed minimal participation in classroom activities during mathematics instruction, it appeared that students were either afraid of the subject or did not feel a strong motivation to learn it. This surely negatively affected their achievement in mathematics. Teachers reported that students were nervous in math lessons, but observations suggested that teachers' static teaching styles may also explain their poor achievement and apparent lack of motivation. Teachers tended to rely only on the textbook and did not use other forms of instructional media, largely because the school could not provide it. The result was that many students found their classes monotonous and boring.

Using collaborative learning groups and concrete objects in the classroom however seemed to relieve this monotony. Students interviewed said that they found this approach to teaching and learning more fun and challenging. They reported helping each other in group discussions and motivating each other when one of them had to present the results of their discussion in front of the rest of the class. They also said that they felt happy when they were given the opportunity to write on the whiteboard and receive feedback from their teacher and their classmates. As the teacher shifted away from a traditionally arranged classroom and teachercentered instruction to a more facilitative style and studentarranged classroom, her class seemed to be more alive and active. More students appeared to by asking question. Students reported that they felt happier and more motivated when their teacher gave them positive rewards for their efforts to learn. Thus collaborations with teachers at Al-Jauharotunnaqiyah suggest that student motivation and achievement are improved by a supportive learning environment in which the teacher uses a variety of instructional strategies and media to accomplish instructional objectives.

\section{References}

Bjork, Christopher. 2003. "Local Responses to Decentralization Policy in Indonesia.” Comparative Education Review 47 (2): 184-216.

Chickering, Arthur, and Zelda Gamson. 1987. "Seven Principles for Good Practice in Undergraduate Education." American Association of Higher Education Bulletin 39 (7): 3-7.

House, J. Daniel. 2009. "Effects of Classroom Instructional Strategies and Self-Beliefs on Science Achievement of Elementary Schools Students in Japan: Results from the TIMSS 2003 Assessment.” Education 129 (2): 259-264.

Johnson, David W., Roger T. Johnson, and Karl A. Smith. 1998. "Cooperative Learning Returns to College: What Evidence is There That it Works?" Change 30 (4): 26-35.

Keyser, Marcia. 2000. "Active Learning and Cooperative Learning: Understanding the Difference and Using Both Styles Effectively." Research Strategies 17 (1): 35-44.

Niemi, Hannele. 2002. "Active Learning-A Cultural Change Needed in Teacher Education and Schools." Teaching and Teacher Education 18 (7): 763-780.

Organisation for Economic Co-operation and Development (OECD). 2009. Creating Effective Teaching and Learning Environments: First Results from TALIS. Paris: OECD.

Prince, Michael. 2004. "Does Active Learning Work? A Review of the Research.” Journal of Engineering Education 93 (3): 19.

Silberman, Mel. 1996. Active Learning: 101 Strategies to Teach any Subject. Boston, MA: Allyn and Bacon.

Stern, David, and Günter Huber, eds. 1997. Active Learning for Students and Teachers: Reports from Eight Countries. New York: Peter Lang.

Stringer, Ernest. 2007. Action Research. 3rd ed. Thousand Oaks, CA: SAGE Publications. 